\title{
Article \\ Flow Pd(II)-Catalysed Carbonylative Cyclisation in the Total Synthesis of Jaspine B
}

\author{
Pavol Lopatka ${ }^{1}$, Michal Gavenda ${ }^{1}$, Martin Markovič ${ }^{1,2, *}$, Peter Koóš ${ }^{1,2, *}$ and Tibor Gracza ${ }^{1}$ \\ 1 Institute of Organic Chemistry, Catalysis and Petrochemistry, Slovak University of Technology, Radlinského 9, \\ 81237 Bratislava, Slovakia; pavol.lopatka@stuba.sk (P.L.); michal.gavenda@stuba.sk (M.G.); \\ tibor.gracza@stuba.sk (T.G.) \\ 2 Georganics, Ltd., Koreničova 1, 81103 Bratislava, Slovakia \\ * Correspondence: martin.markovic@stuba.sk (M.M.); peter.koos@stuba.sk (P.K.); Tel.: +421-259-325-129 (P.K.)
}

check for updates

Citation: Lopatka, P.; Gavenda, M.; Markovič, M.; Koóš, P.; Gracza, T. Flow Pd(II)-Catalysed Carbonylative Cyclisation in the Total Synthesis of Jaspine B. Catalysts 2021, 11, 1513. https://doi.org/10.3390/catal11121513

Academic Editor: Laura

Antonella Aronica

Received: 26 November 2021

Accepted: 9 December 2021

Published: 12 December 2021

Publisher's Note: MDPI stays neutral with regard to jurisdictional claims in published maps and institutional affiliations.

Copyright: (c) 2021 by the authors. Licensee MDPI, Basel, Switzerland. This article is an open access article distributed under the terms and conditions of the Creative Commons Attribution (CC BY) license (https:// creativecommons.org/licenses/by/ $4.0 /)$.

\begin{abstract}
This work describes the total synthesis of jaspine B involving the highly diastereoselective $\mathrm{Pd}(\mathrm{II})$-catalysed carbonylative cyclisation in the preparation of crucial intermediates. New conditions for this transformation were developed and involved the $p \mathrm{BQ} / \mathrm{LiCl}$ as a reoxidation system and $\mathrm{Fe}(\mathrm{CO})_{5}$ as an in situ source of stoichiometric amount of carbon monoxide (1.5 molar equivalent). In addition, we have demonstrated the use of a flow reactor adopting proposed conditions in the large-scale preparation of key lactones.
\end{abstract}

Keywords: Jaspine B; flow chemistry; palladium catalysis; cyclisation; carbonylation

\section{Introduction}

The examination of natural resources clearly remains the basis of the discovery of new bioactive substances. Since these newly discovered natural compounds become the inspiration for novel drug candidates, many groups in the scientific community create their research programs aiming at these novel structures. As a result, the newly developed transformations are then presented in terms of their applicability in the synthesis of such targets. However, in many cases such synthetic demonstrations do not provide accessibility to all derivatives and/or usable amounts of promising target molecule for further testing. In particular, progress in later stages of pharmaceutical/biomedical research might then be negatively affected. Although the synthetic optimisation is not so scientifically valued in the chemical community, it is still of great importance. This is especially so today when we are facing environmental and climate changes and need to be concerned about a sustainable future.

Since its discovery, jaspine B (pachastrissamine) 1 has drawn an immense attention from the scientific community (Figure 1).

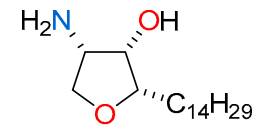

Jaspine B (1)

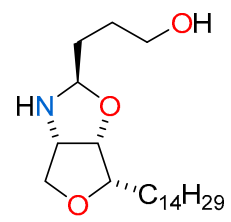

Jaspine A (2)

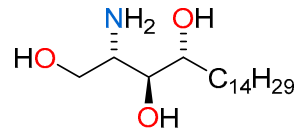

D-ribo-phytosphingosine (3)
Figure 1. Structure of pachastrissamine (jaspine B) (1), jaspine A (2) a D-ribophytosphingosine (3).

This natural sphingolipid 1 was independently isolated in 2002 and 2003 by T. Higa et al. and by the C. Debitus group from marine sponges, Pachastrissa sp. (family Calthropellidae) and Jaspis sp., respectively [1,2]. Due to its similar structure to other bioactive sphingolipids, jaspine B $\mathbf{1}$ has been also tested for its pharmacological properties and it has shown in vitro cytotoxic activity against several types of cancer cell (A-549, P-388, HT-29, 
MeL-28, MCF-7, KB, HCT-116, U2OS, MDA-231. HeLa, CNE, MGC-803, EC-9706, PC-3, A-375, WM-115, Caco-2, Jurkat, SNU-638 and Caki-1) in the micro and sub-micromolar range [1-15]. The group of Y. Salma described how the cytotoxic activity of jaspine B 1 is based on the inhibition of SMS (sphinghomyelin synthetase) enzyme activity, which is responsible for maintaining stable concentration levels of ceramides (Cer) in the cell. Thus, higher concentration of Cer induces the cell apoptosis by a caspase-dependent pathway.

To this date, an enormous effort has been made to prepare and study this natural compound 1. There are 35 known syntheses of jaspine B 1, ten of which are based on an asymmetric step [12,16-24] and twenty-five are chiral pool approaches $[4,8,9,25-45]$. Moreover, the promising biological activity of this natural compound has resulted in the syntheses of various derivatives of this molecule for structure-activity relationship study purposes (Figure 2).

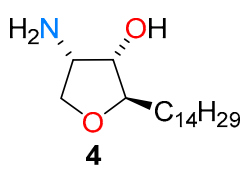

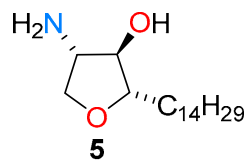

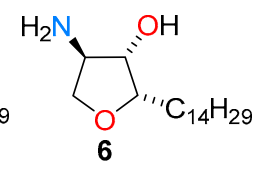<smiles>[R]C1OC[C@@H](N)[C@H]1O</smiles>

7 (R: - $\left.\left(\mathrm{CH}_{2}\right)_{11} \mathrm{OH}\right)$<smiles>N[C@H]1CO[C@@H](CCc2ccc(F)cc2)[C@@H]1O</smiles><smiles>COc1ccc(CCC2OCC(N)C2O)cc1</smiles>

9 (R: - $\left.\left(\mathrm{CH}_{2}\right)_{11} \mathrm{CH}_{3}\right)$

10<smiles>CCc1ccc(CC[C@@H]2OCC(N)[C@H]2O)cc1</smiles>

$\mathrm{H}_{2} \mathrm{~N}$<smiles>CCC/C=C/[C@H]1OCC(N)C1O</smiles>

12<smiles></smiles>

20<smiles>[R]C1[X]CC(N)[C@H](O)[C@@H]1[R]</smiles>

14 (X: S, R: $\left.\mathrm{C}_{14} \mathrm{H}_{29}\right)$ 15 (X: Se, R: $\left.\mathrm{C}_{14} \mathrm{H}_{29}\right)$ $16\left(X: N, R: \mathrm{C}_{14} \mathrm{H}_{29}\right)$ $17\left(\mathrm{X}: \mathrm{CH}_{2}, \mathrm{R}: \mathrm{C}_{14} \mathrm{H}_{29}\right)$ $18\left(\mathbf{X}: \mathrm{CH}_{2}, \mathrm{R}: \mathrm{C}_{12} \mathrm{H}_{25}\right)$ $19\left(\mathrm{X}: \mathrm{CH}_{2}, \mathrm{R}: \mathrm{C}_{16} \mathrm{H}_{33}\right)$

Figure 2. Synthetic derivatives of jaspine B 1.

In summary, the biological activity of $\mathbf{1}$ has been found to be highly dependent on the stereo-configuration of the ring substituents and on the length of the aliphatic chain of the natural product $[4,9]$. The best bioactivity was observed while keeping the original configuration and the length of aliphatic chain [31]. However, the oxygen atom in the heterocycle of jaspine B 1 has not been found to be crucial for its cytotoxic properties [46].

\section{Results and Discussion}

In the course of our long-term research program directed towards $\mathrm{CO}$ gas-free carbonylative cyclisations, flow transformations and their synthetic applications, we have developed a new flow protocol for Pd-catalysed carbonylation reactions based on the use of iron pentacarbonyl [47]. To this date, only a few flow applications of this stereoselective reaction are reported in the literature. However, many total syntheses of natural products utilised this transformation as a batch process [48-50]. As a result, the reaction conditions have undergone many changes and the reoxidation system as one of the most modified parameters has been varied/adjusted from its original conditions to substrate specific requirements $\left(p \mathrm{BQ} / \mathrm{CuCl}_{2} / \mathrm{O}_{2}\right)[51,52]$.

Based on the previous results and our experience with the Pd-catalysed carbonylation in the total synthesis of natural products, we have proposed a total synthesis of jaspine B 1 utilising the flow carbonylative step as a key transformation. 


\subsection{Total Synthesis of Jaspine B}

The synthesis of jaspine B 1 was designed to build the chiral centres via the stereoselective Pd-catalysed carbonylation. In addition, the synthesis was optimised to reach one of the key aspects - the compatibility of batch reaction conditions for the following application in the flow system. Thus, this key transformation would provide $N$-protected lactone 21 with correct configuration at chiral centres. The substrate for this cyclisation-unsaturated $\mathrm{N}$-protected amino diol can be easily accessible from L-serine (Scheme 1).

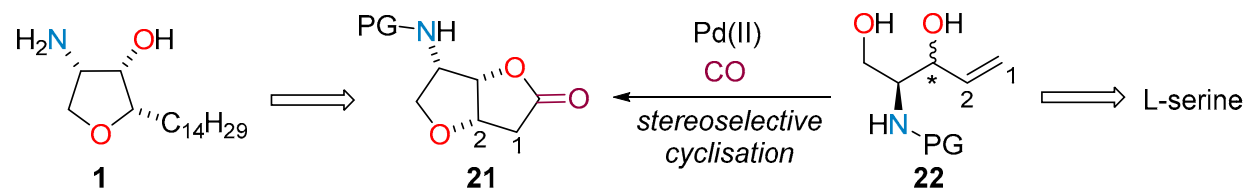

Scheme 1. Retrosynthetic analysis of jaspine B 1.

As depicted in the retrosynthetic analysis, further transformation (chain elongation) of lactone 21 functional group would lead to the natural jaspine B.

Accordingly, the synthesis of $\mathbf{1}$ started from a commercially available $\mathrm{N}$-Boc ( $\mathrm{N}$-tbutoxycarbonyl) protected Garner's aldehyde 26-Boc. This aldehyde 26-Boc can be easily prepared in few synthetic steps starting from L-serine. The whole sequence involving an esterification of L-serine, amino group protection of derivate 23 , the formation of oxazolidine $\mathbf{2 5}$ and the following reduction of the ester group is very well described in the literature [53] (Scheme 2).

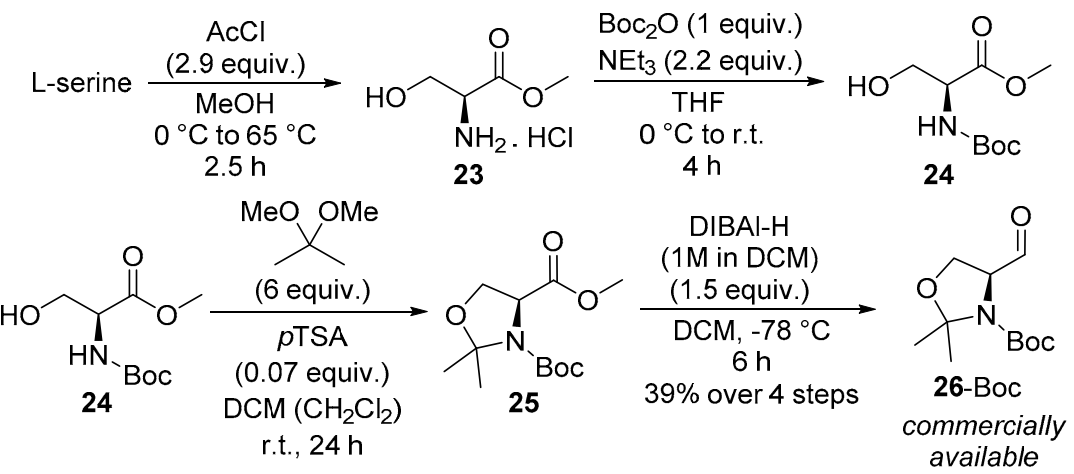

Scheme 2. Preparation of N-Boc protected Garner's aldehyde 27-Boc.

At the beginning, the N-Boc protected Garner's aldehyde 26-Boc was transformed to unsaturated $N$-Boc protected aminodiol 22-Boc by a two step sequence (Scheme 3a) [54]. In detail, the addition of vinylmagnesium bromide to the starting aldehyde 26-Boc in THF (tetrahydrofuran) provided a mixture of diastereomeric alcohols $27-$ Boc in $91 \%$ yield. The selectivity of this reaction varies from 90:10 to 60:40 depending on the reaction temperature [54-56]. The major isomer, 2S,3R-alcohol 27-Boc leads to a final product 1 with correct stereo configuration. The following selective deprotection of the acid labile oxazolidine group of 27-Boc using $p$ TSA ( $p$-toluenesulfonic acid) provided $N$-Boc protected aminodiols 22-Boc in $76 \%$ yield as an inseparable mixture [57]. Such a mixture of diastereomeric alcohols was then submitted to Pd-catalysed carbonylative cyclisation. This reaction was performed using well-established conditions with $\mathrm{Fe}(\mathrm{CO})_{5}$ as a $\mathrm{CO}$ surrogate and the desired products-lactones 21-Boc were obtained in 75\% combined yield. At this stage, the lactone 21-Boc with all syn configuration was separated using MPLC as a major substance from the diastereomeric mixture. Next, the reduction of lactone functional group using DIBAL-H (diisobutylaluminum hydride) provided lactol 28-Boc in $88 \%$ yield (Scheme $3 \mathrm{~b}$ ). 


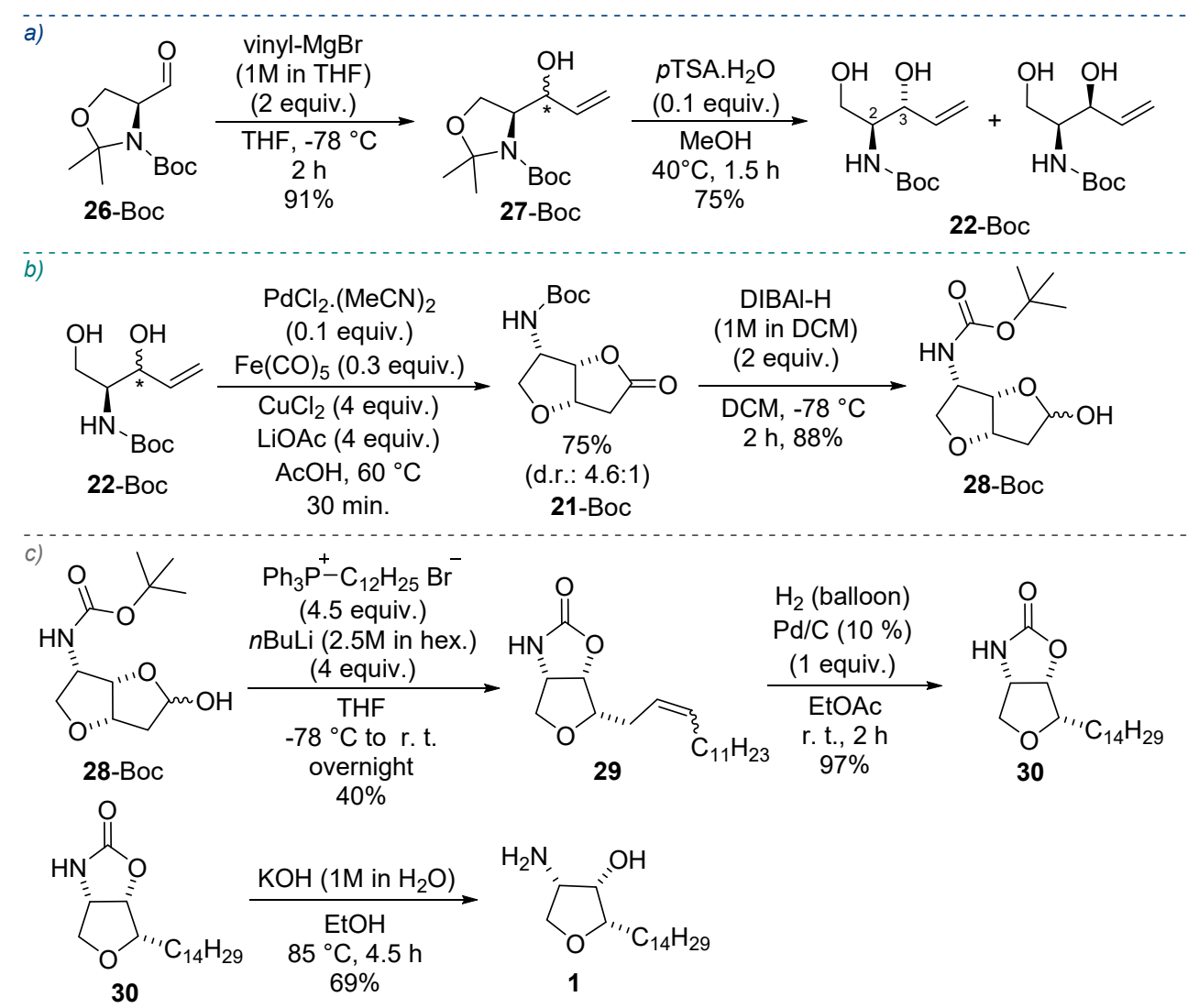

Scheme 3. Total synthesis of jaspine B 1.

The final step sequence included a Wittig reaction, double bond reduction and oxazolidinone cleavage (Scheme 3c). These synthetic steps have already been described in the literature and the authors used them to furnish the final natural compound $\mathbf{1}$ by employing $\mathrm{N}-\mathrm{Cbz}$ ( $\mathrm{N}$-benzyloxycarbonyl) protected lactone $21-\mathrm{Cbz}$ as a starting material [35]. However, based on the inspection of spectroscopic data, Davies et al. [58] later described the epimerization at $\mathrm{C}-2$ carbon occurred during the Wittig reaction and the authors prepared 2-epi-jaspine B [35]. This discrepancy was accounted for by a retro-Michael/Michael epimerisation reaction pathway upon treatment of lactol 28 with excess Wittig reagent (Scheme 4b).

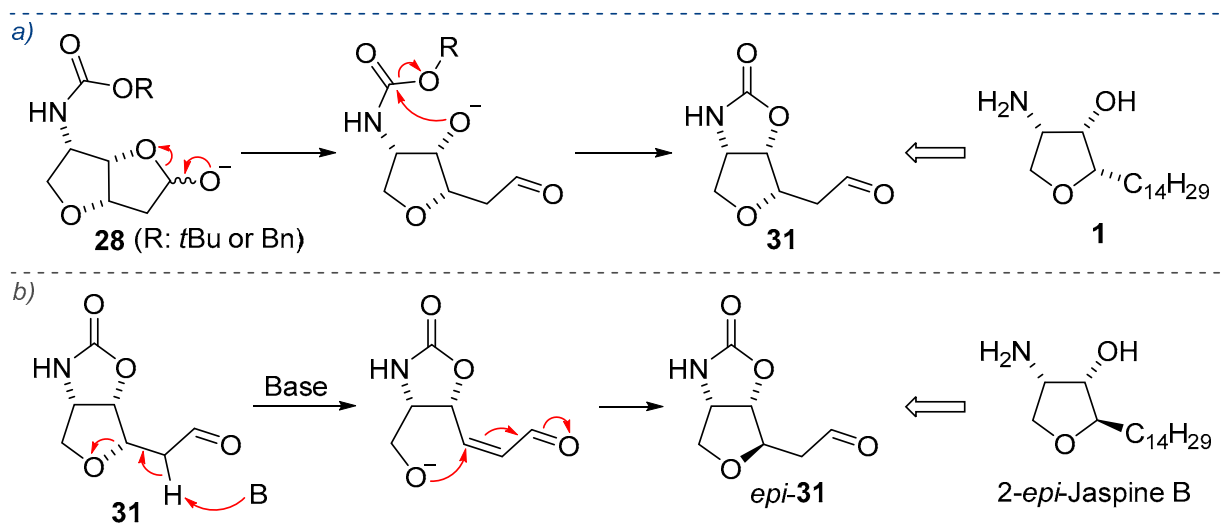

Scheme 4. Formation of oxazolidinone ring (a) and possible epimerisation at C-2 carbon in Wittig reaction $(\mathbf{b})$.

The authors later described how this epimerisation occurred in the DIBAL-H reduction step using old reagent containing base via same reaction pathway [15]. 
In our case, by applying the described conditions we were able to prepare the chiral oxazolidinone 29-Boc in 40\% yield. The formation of oxazolidinone ring via intramolecular attack of the hydroxy anion to the carbamate group furnished aldehyde 31 (Scheme 4a). Following a reduction of the double bond using $\mathrm{Pd} / \mathrm{C}$ and $\mathrm{H}_{2}$ gave compound 30 in $97 \%$ yield. Finally, jaspine B $\mathbf{1}$ was provided by a cleavage of the oxazolidinone ring of $\mathbf{3 0}$ using aqueous $\mathrm{KOH}$ in $69 \%$ yield. The comparison of spectroscopic data of prepared jaspine B 1 to described data [34] revealed that the epimerisation of $\mathbf{3 1}$ during Wittig reaction or reduction has not occurred.

In summary, we have accomplished the total synthesis of jaspine B 1 in seven steps starting from $\mathrm{N}$-Boc protected Garner's aldehyde. The stereoselective $\mathrm{Pd}(\mathrm{II})$-catalysed carbonylative cyclisation was used in the preparation of key intermediate-lactone 21-Boc. The yield of jaspine B was 10\% over all synthetic steps.

In addition, the synthesis of jaspine $B$ was also performed starting from the commercially available $\mathrm{N}-\mathrm{Cbz}$ protected Garner's aldehyde 26-Cbz. Following the same synthetic route, we were able to increase the overall yield of jaspine B up to $16 \%$ yield over seven reaction steps (Scheme 5).
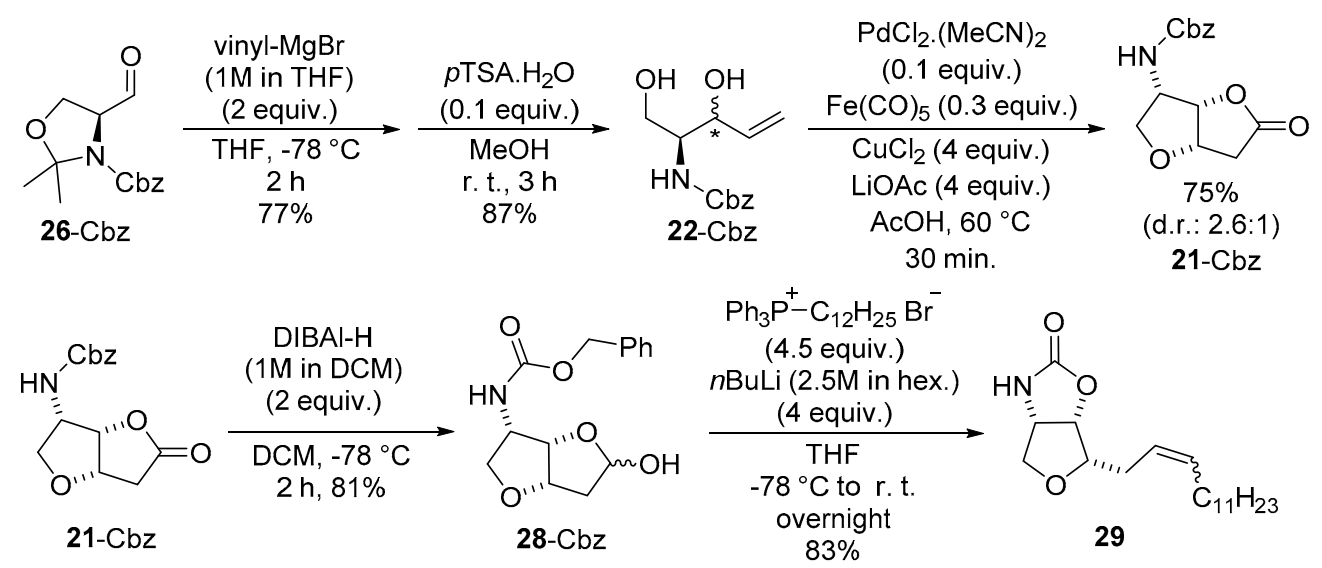

Scheme 5. Synthesis of jaspine B 1 via N-Cbz protected lactone.

Similarly, the Wittig reaction of lactol 28-Cbz proceeded cleanly to oxazolidinone 29 without unwanted epimerisation at the C-2 carbon centre as in the previous case and the desired product 29 was isolated in $83 \%$ yield.

After successful optimisation of the total synthesis of jaspine B in batch, we focused our attention on the application of flow chemistry for the preparation of key intermediatelactone 21. Thus, the flow $\mathrm{Pd}(\mathrm{II})$-catalysed carbonylative cyclisation of $\mathbf{2 2}$ was proposed.

\subsection{Flow Synthesis of the Key Intermediate $\mathbf{2 1}$ for the Preparation of Jaspine B $\mathbf{1}$}

Over the last few decades, the flow chemistry has shown many advantages in organic synthesis, and it has grown into a modern and enabling tool for new synthetic methods utilising dangerous and/or toxic chemicals $[59,60]$. Moreover, many total syntheses of various biorelevant compounds have utilised this technique as a fundamental instrument in the preparation of key intermediates [61-63] or as a multiple step telescoped system [64-66]. At present, the flow chemistry has become an integral part of scientific research and it is commonly used in synthetic laboratories at universities and in pharmaceutical companies.

The flow chemistry technique as a part of our research program has been used in the application of $\mathrm{CO}$ surrogates in the carbonylative transformations. We have previously demonstrated that $\mathrm{Fe}(\mathrm{CO})_{5}$ can be utilised as a $\mathrm{CO}$ donor in $\mathrm{Pd}(\mathrm{II})$-catalysed carbonylative cyclisation [47]. In the continuation of our research, we have focused on the development of new conditions for this flow transformation and on its application in the flow synthesis of bioactive compounds. Thus, we have proposed a new flow system for the preparation of the key intermediate $\mathbf{2 1}$ in the jaspine B 1 synthesis (Figure 3). 


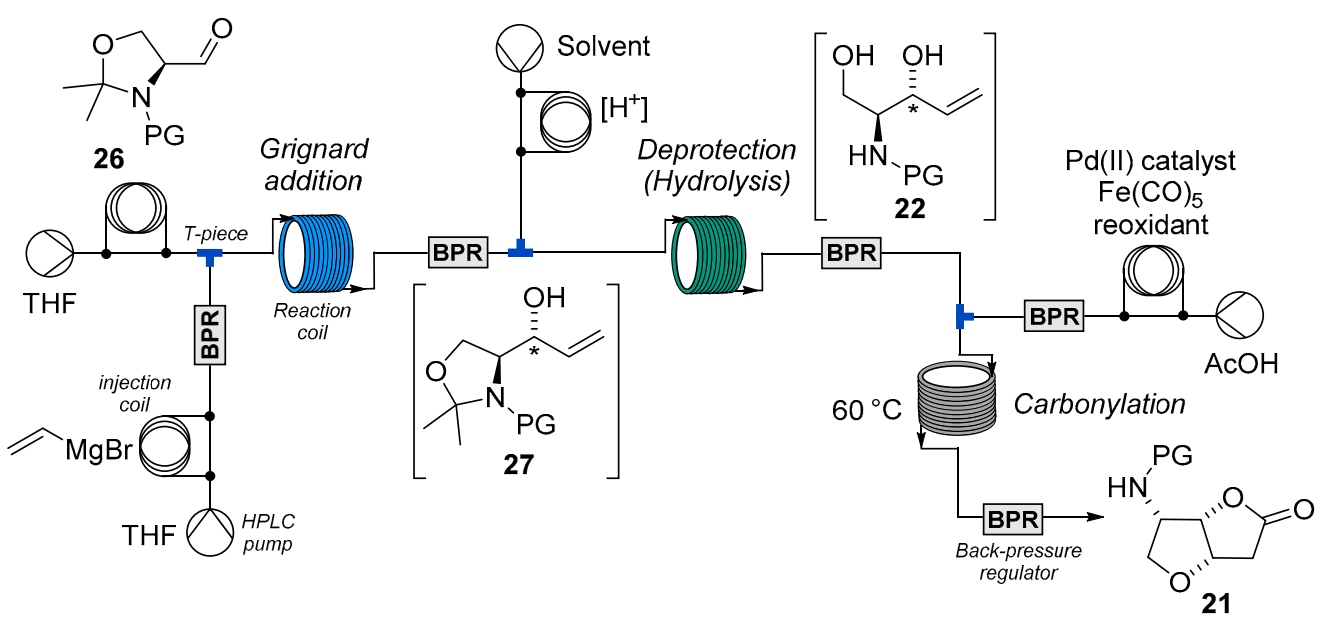

Figure 3. Proposed telescoped flow system for the synthesis of bicyclic lactone 21.

The proposed telescoped flow system consists of three parts involving the Grignard addition, selective deprotection and crucial cyclisation. The aim of the design was to perform these steps in a one-telescoped system without executing any isolation procedure. Consequently, the flow system would provide the crude final lactone 21 starting from commercially available substrates.

Our investigation started with a series of batch experiments aimed to address the minimal requirements and compatibility of reaction conditions for flow procedure. At first, we examined various reaction conditions of the first two steps sequence of the total synthesis-addition of vinyl magnesium bromide to $N$-protected Garner's aldehyde 26 and selective cleavage of oxazolidine $\mathbf{2 7}$ without the isolation after the first step (Scheme 6).

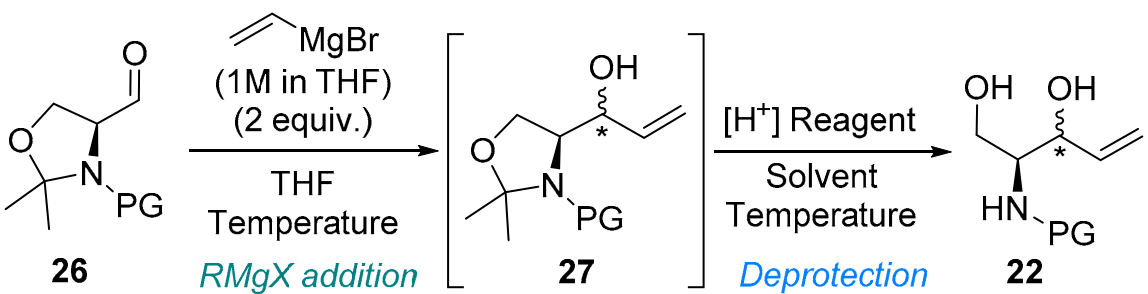

Scheme 6. Optimisation of the RMgX addition and deprotection reaction sequence.

Compared to the previously described batch conditions (Scheme 3a), we tried and modified mainly the cleavage of 2,2-dimethyl oxazolidine 27 using different acidic conditions (Table 1). The best results were achieved using $p$ TSA. $\mathrm{H}_{2} \mathrm{O}$ as a $\mathrm{H}^{+}$source in $\mathrm{MeOH}$ in the second step (Table 1, Entry 1 and 5). Following products 22-Cbz and 22-Boc were isolated in $87 \%$ and $75 \%$ yield over two steps, respectively. In general, altering the temperature of $\mathrm{RMgX}$ addition did not affect the yield of this sequence and only the difference in the diastereoselectivity outcome was observed. The addition step at $0{ }^{\circ} \mathrm{C}$ of this two-step procedures provided in all cases a 1:1 mixture of diastereomeric alcohols 22. In addition, the $\mathrm{SO}_{3} \mathrm{H}$ polymer supported resin, Amberlyst 15 was also tried for the deprotection step as the implementation of polymer supported reagents in flow reactions is described very well $[64,67]$. In this case, the yield of product 22-Boc was decreased due to the partial cleavage of an acid labile $\mathrm{N}$-Boc protecting group of substrate 26-Boc. The formation of completely deprotected aminodiol 22 was confirmed by LC-MS analysis and the full cleavage of protecting groups of 26-Boc was also observed in the case of the reaction performed in $\mathrm{AcOH}$ (Table 1, entry 3). 
Table 1. Optimisation of the $\mathrm{RMgX}$ addition and deprotection reaction sequence in batch.

\begin{tabular}{|c|c|c|c|c|c|c|c|c|}
\hline \multirow[b]{2}{*}{ Entry } & \multirow[b]{2}{*}{ Substrate } & \multicolumn{2}{|c|}{ RMgX Addition } & \multicolumn{4}{|c|}{ Deprotection } & \multirow{2}{*}{\begin{tabular}{|c|} 
Product \\
Yield (\%)
\end{tabular}} \\
\hline & & $\mathrm{T}\left({ }^{\circ} \mathrm{C}\right)$ & $\begin{array}{l}\text { Rxn } \\
\text { Time }\end{array}$ & $\begin{array}{l}\left.\text { [H }{ }^{+}\right] \text {Reagent } \\
\text { (Equivalent) }\end{array}$ & Solvent & $\mathrm{T}\left({ }^{\circ} \mathrm{C}\right)$ & $\begin{array}{l}\text { Rxn } \\
\text { Time }\end{array}$ & \\
\hline 1 & 26-Boc & -78 & $2 \mathrm{~h}$ & pTSA. $\mathrm{H}_{2} \mathrm{O}(0.1)$ & $\mathrm{MeOH}$ & $40^{\circ} \mathrm{C}$ & $1.5 \mathrm{~h}$ & 75 \\
\hline 2 & 26-Boc & 0 & $2 \mathrm{~h}$ & $\begin{array}{c}\text { Amberlyst } 15 \\
(3.2)^{b}\end{array}$ & $\mathrm{MeOH}$ & $40^{\circ} \mathrm{C}$ & $0.5 \mathrm{~h}$ & $46^{c}$ \\
\hline 3 & 26-Boc & 0 & $2 \mathrm{~h}$ & - & $\mathrm{AcOH}$ & $70^{\circ} \mathrm{C}$ & $0.5 \mathrm{~h}$ & $35^{c}$ \\
\hline 4 & 26-Cbz & -78 & $1.5 \mathrm{~h}$ & - & $\begin{array}{c}\mathrm{AcOH} / \mathrm{H}_{2} \mathrm{O} \\
(4 / 1)\end{array}$ & r.t. & $3 \mathrm{~h}$ & 59 \\
\hline 5 & $26-\mathrm{Cbz}$ & -78 & $1.5 \mathrm{~h}$ & $p$ TSA. $\mathrm{H}_{2} \mathrm{O}(0.1)$ & $\mathrm{MeOH}$ & r.t. & $3 \mathrm{~h}$ & 87 \\
\hline 6 & $26-\mathrm{Cbz}$ & 0 & $1.5 \mathrm{~h}$ & $\begin{array}{c}\text { Amberlyst } 15 \\
(3.2)^{b}\end{array}$ & $\mathrm{MeOH}$ & $40^{\circ} \mathrm{C}$ & $0.5 \mathrm{~h}$ & 73 \\
\hline
\end{tabular}

${ }^{a}$ Yield based on the amount of isolated product 22. ${ }^{\mathrm{b}}$ The capacity of Amberlyst 15 is $4.7 \mathrm{~m}$ equivalents per $1 \mathrm{~g}$ by dry weight. ${ }^{\mathrm{c}}$ Partial cleavage of $N$-Boc protecting group was observed by LC-MS analysis.

Based on the optimisation of reaction sequence under batch conditions, we performed a series of experiments using a flow system as depicted in Scheme 7 . At first, only nucleophilic addition of $\mathrm{RMgX}$ was examined. In this case, the second stage of the flow setup was omitted, and the Grignard reaction was performed at $0{ }^{\circ} \mathrm{C}$ to ensure the homogeneity of the reaction stream (the reaction at $-78{ }^{\circ} \mathrm{C}$ is not homogeneous). Thus, the flow reaction using a $9 \mathrm{~mL}$ reactor coil provided products 27 with full conversion of substrates 26 in acceptable yields with lower stereoselectivity (Table 2, entry 1 and 2).

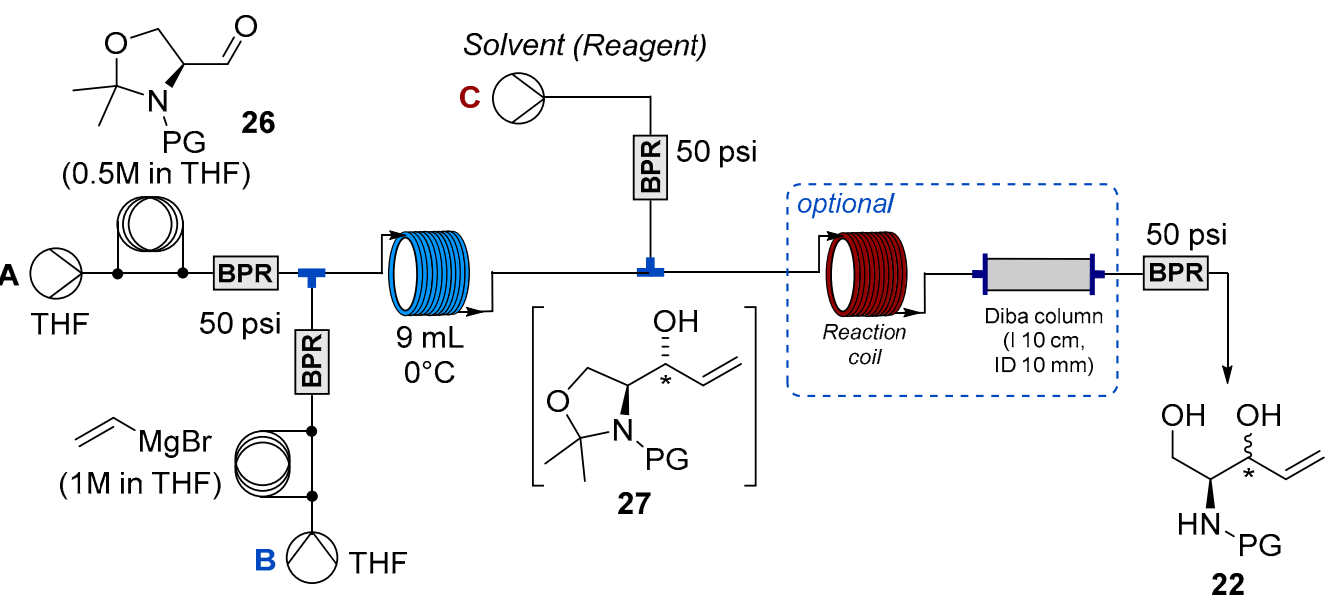

Scheme 7. Optimisation of the flow addition/deprotection reaction sequence.

The following flow experiments employing the second stage of the system were performed using a reaction coil or Diba column (optional) depending on the use of $\mathrm{H}^{+}$ donor in the acetonide deprotection step. In the case of the reaction using an excess of Amberlyst 15 ( $1.7 \mathrm{~g}, 8$ equivalents) in the Diba column, the reagent also secured the filtration of reaction stream and $\mathrm{Mg}$ (II) salts formed after mixing (quenching) the Grignard reaction stream with $\mathrm{MeOH}$ were caught on the polymer resin. However, the larger excess of Amberlyst 15 also caused a parallel carbamate cleavage and decreased the yield of products. Thus, the flow system using Amberlyst 15 provided products 22-Boc and 22-Cbz in 34 and $49 \%$ yield, respectively (Table 2, entry 3 and 4).

The best results were achieved using $1.1 \mathrm{M}$ solution of $p \mathrm{TSA}$ in $\mathrm{MeOH}$ in the second step and the products were isolated in similar yields to batch (Table 2, entry 5 and 6). In this case, the concentration and flow rate of para-toluenesulfonic acid stream were adjusted to ensure the catalytic amount of $\mathrm{H}^{+}$necessary for the deprotection of acetonide group. 
Since, the 0.25 of $0.275 \mathrm{mmol} / \mathrm{min}$ amount of this acid was immediately quenched in the reactor by the excess of $\mathrm{Mg}$ (II) salts, the $0.275 \mathrm{mmol} / \mathrm{min}$ amount really represents only the catalytic amount of $\mathrm{H}^{+}$. Thus, the flow reactions using $8.65 \mathrm{mmol}$ of substrates 27-Cbz or 27-Boc led to the formation of desired $\mathrm{N}$-protected unsaturated aminodiols 22 in 82 and $62 \%$ yields, respectively (Table 2, entry 5 and 6). With optimised conditions for this addition/deprotection sequence in hand, we turned our attention to the continuous carbonylative cyclisation step.

Table 2. Optimisation of the flow addition/deprotection reaction sequence.

\begin{tabular}{|c|c|c|c|c|c|c|c|c|c|}
\hline \multirow{3}{*}{ Entry } & \multirow{3}{*}{$\begin{array}{l}\text { Substrate } \\
\text { 26-PG }\end{array}$} & \multicolumn{6}{|c|}{ STREAM } & \multirow{3}{*}{$\begin{array}{l}\text { Optional } \\
\text { Equipment }\end{array}$} & \multirow{3}{*}{$\begin{array}{c}\text { Yield }^{b} \\
(\%)\end{array}$} \\
\hline & & \multicolumn{2}{|c|}{$\mathbf{A}^{\mathrm{a}}$} & \multicolumn{2}{|c|}{ B } & \multicolumn{2}{|c|}{$\mathrm{C}$} & & \\
\hline & & $\begin{array}{l}\text { Inj. Coil } \\
\text { (mL) }\end{array}$ & $\begin{array}{l}\text { Flow Rate } \\
\text { (mL/min.) }\end{array}$ & $\begin{array}{l}\text { Inj. Coil } \\
\text { (mL) }\end{array}$ & $\begin{array}{l}\text { Flow Rate } \\
\text { (mL/min.) }\end{array}$ & Solvent & $\begin{array}{l}\text { Flow Rate } \\
\text { (mL/min.) }\end{array}$ & & \\
\hline 1 & Boc & 2 & 0.3 & 2.3 & 0.3 & - & - & & $84^{c}$ \\
\hline 2 & $\mathrm{Cbz}$ & 2 & 0.25 & 2.3 & 0.25 & - & - & & $66^{c}$ \\
\hline 3 & Boc & 2 & 0.3 & 2.3 & 0.3 & $\mathrm{MeOH}$ & 0.6 & $\begin{array}{c}1.7 \mathrm{~g} \\
\text { (Amberlyst) }\end{array}$ & $34^{\mathrm{d}}$ \\
\hline 4 & $\mathrm{Cbz}$ & 2 & 0.25 & 2.3 & 0.25 & $\mathrm{MeOH}$ & 0.5 & $\begin{array}{c}1.7 \mathrm{~g} \\
\text { (Amberlyst) }\end{array}$ & 49 \\
\hline 5 & Boc & 17.3 & 0.25 & 18.4 & 0.25 & $\begin{array}{c}p \mathrm{TSA} \text { in } \\
\mathrm{MeOH} \\
(1.1 \mathrm{M})\end{array}$ & 0.25 & $\begin{array}{c}\text { reaction coil } \\
\left(10 \mathrm{~mL}, 50^{\circ} \mathrm{C}\right)\end{array}$ & 62 \\
\hline 6 & $\mathrm{Cbz}$ & 17.3 & 0.25 & 18.4 & 0.25 & $\begin{array}{l}p \text { TSA in } \\
\mathrm{MeOH} \\
(1.1 \mathrm{M})\end{array}$ & 0.25 & $\begin{array}{c}\text { reaction coil } \\
\left(10 \mathrm{~mL}, 50^{\circ} \mathrm{C}\right)\end{array}$ & 82 \\
\hline
\end{tabular}

${ }^{\mathrm{a}} 0.5 \mathrm{M}$ solution of substrate in THF (tetrahydrofuran) was used. ${ }^{\mathrm{b}}$ Yield based on the amount of isolated product $22 .{ }^{\mathrm{c}}$ Only addition step was performed in the flow system, the yield corresponds to the addition product 27. ${ }^{\mathrm{d}}$ Deprotection of $N$-Boc group was also observed.

In 2018, we reported on pros and cons of the flow and batch stereoselective Pdcatalysed carbonylative cyclisation of unsaturated polyols/aminoalcohols using known conditions [68] and $\mathrm{Fe}(\mathrm{CO})_{5}$ as an in situ donor of carbon monoxide [47]. By adjusting the concentration of reaction streams and the amount of $\mathrm{Cu}^{2+} / \mathrm{Li}^{+}$inorganic salts required for the reoxidation $\mathrm{Pd}^{0}$, we were able to prepare a series of various cyclisation products in a flow system (Scheme 8).

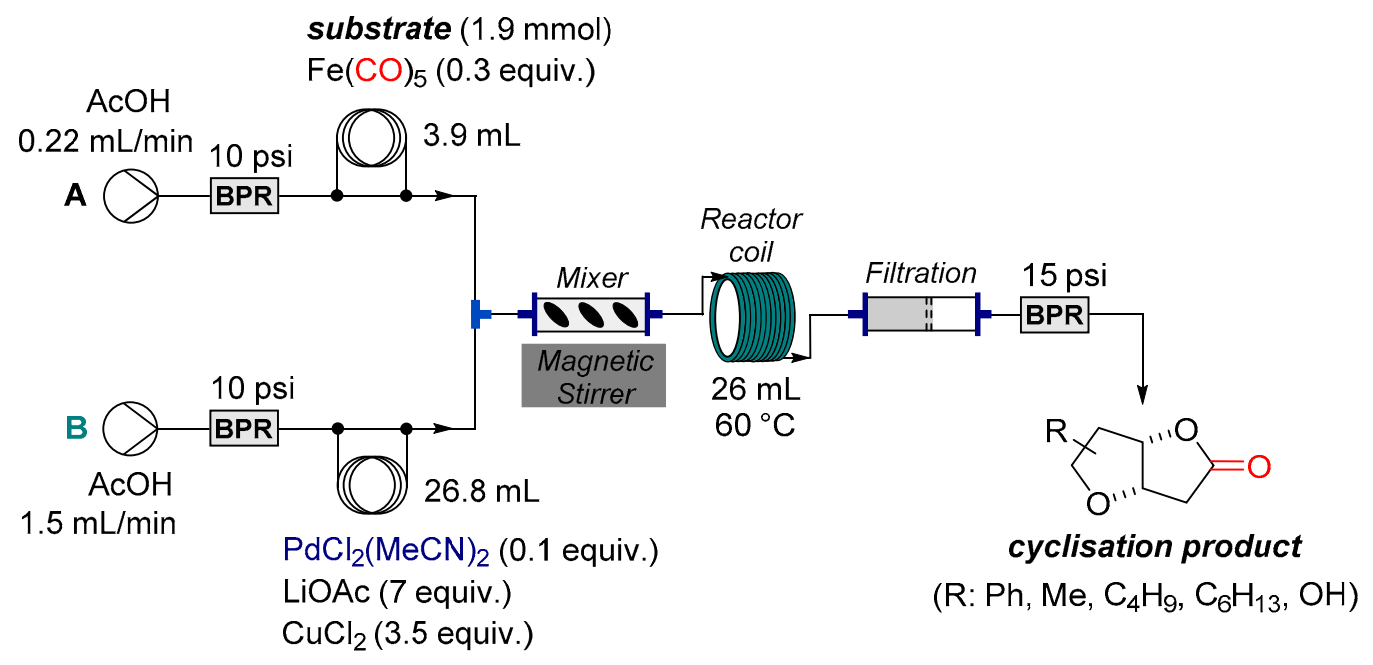

Scheme 8. Previously described continuous Pd(II)-catalysed carbonylation of unsaturated polyols and aminoalcohols.

Even though aforementioned continuous flow system was successfully applied in the large-scale preparation of desired bicyclic lactones, there are still limitations of the 
system regarding the formation of insoluble copper salts in the reactor. Also, an active mixer and interchangeable filtration unit were necessary to perform the transformation over longer periods.

With the aim to improve the conditions for continuous flow Pd-catalysed oxy/ aminocarbonylation, we adopted the use of $p \mathrm{BQ}$ ( $p$-benzoquinone) instead of $\mathrm{Cu}^{2+}$ as a reoxidant.

At first, we performed a batch reaction using 2 equivalents of $p \mathrm{BQ}, 0.6$ equivalent of $\mathrm{Fe}(\mathrm{CO})_{5}$ and 0.1 equivalent $\mathrm{PdCl}_{2}(\mathrm{MeCN})_{2}$ using diastereomeric mixture 22-Boc $(0.23 \mathrm{mmol})$ in acetic acid $\left(0.9 \mathrm{~mL}, 0.25 \mathrm{M}\right.$ reaction). The reaction at $60^{\circ} \mathrm{C}$ proceeded with full conversion of starting material after $1 \mathrm{~h}$, however noticeable amounts of insoluble material were observed. The homogeneity of the reaction mixture over the whole course of reaction was achieved by the addition of 1 equivalent of $\mathrm{LiCl}$. The reaction proceeded smoothly with full conversion of 22-Boc in $1 \mathrm{~h}$ at $60^{\circ} \mathrm{C}$. A comparison of newly optimised and previously described conditions is shown in Figure 4.

\begin{tabular}{l} 
Typical conditions \\
$\mathrm{PdCl}_{2} \cdot(\mathrm{MeCN})_{2}(0.1$ equiv. $)$ \\
$\mathrm{Fe}(\mathrm{CO})_{5}(0.3$ equiv. $)$ \\
\hline $\mathrm{Cu}(\mathrm{OAc})_{2}$ (4 equiv.) \\
$\mathrm{LiCl}(4$ equiv. $)$ \\
$\mathrm{AcOH}, 60^{\circ} \mathrm{C}, 1 \mathrm{~h}$
\end{tabular}

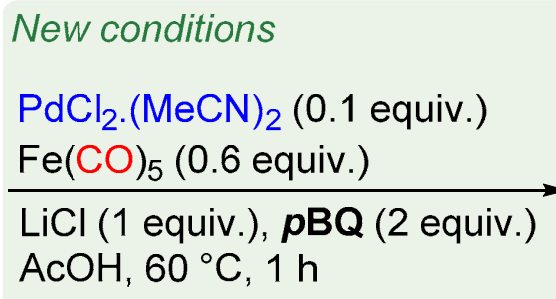

Figure 4. Comparison of known and new conditions for Pd-catalysed carbonylative cyclisation.

The new reaction conditions were then tested in the preparation of key intermediatelactone $\mathbf{2 1}$ for the synthesis of jaspine B $\mathbf{1}$ in continuous flow mode (Scheme 9). The flow setup consisted of two reaction streams which were pumped using HPLC Azura pumps via injection coils to a preheated reactor coil. The composition of stock solutions were adjusted to avoid the decomposition of $\mathrm{Fe}(\mathrm{CO})_{5}$ in the presence of oxidation reagents $(p \mathrm{BQ})$. The following continuous reaction of 22 on $0.5 \mathrm{mmol}$ scale provided the desired $\mathrm{N}$-protected bicyclic lactones $\mathbf{2 1}$ in comparable yields to standard batch and flow conditions (Table 3).

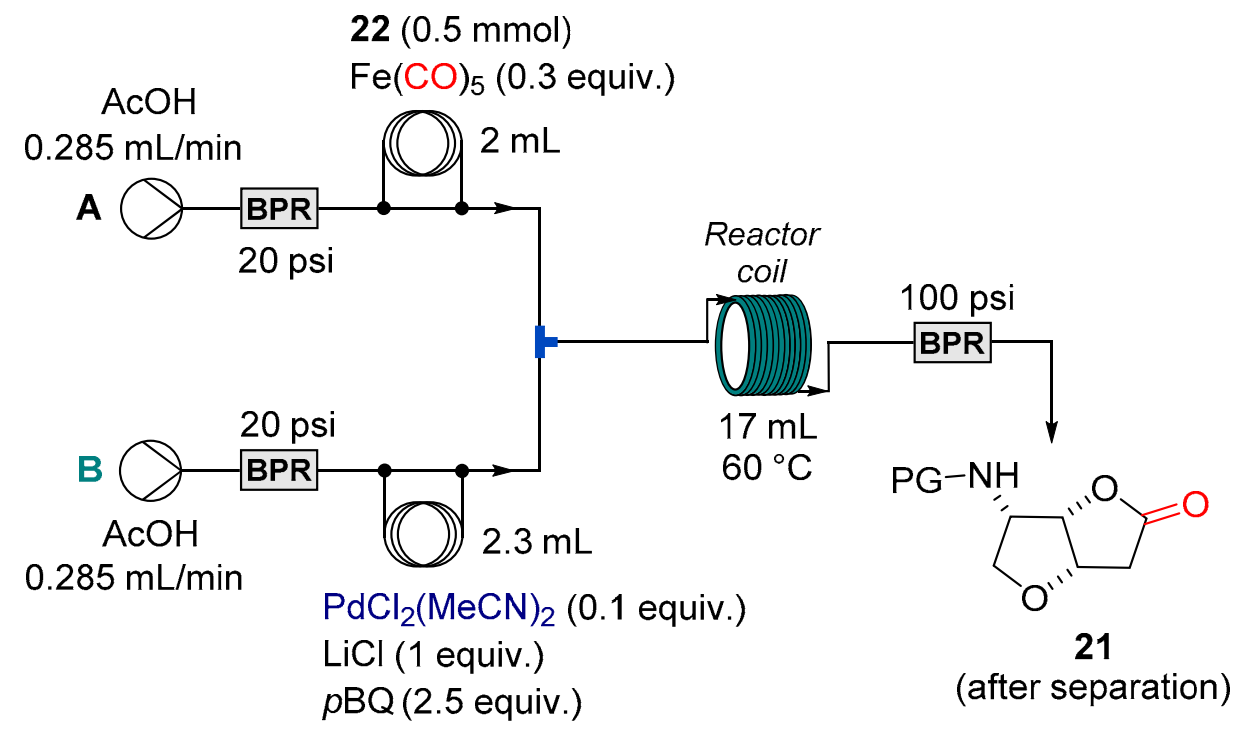

Scheme 9. Continuous Pd(II)-catalysed carbonylations of unsaturated N-protected aminodiols 22. 
Table 3. Comparison of Pd(II)-catalysed carbonylation of 22 employing batch and flow conditions.

\begin{tabular}{ccccc}
\hline \multirow{2}{*}{ Entry } & \multirow{2}{*}{ Product } & \multicolumn{2}{c}{ Typical Conditions } & New Conditions \\
\cline { 3 - 5 } & & Batch Yield $^{\mathbf{a}, \mathbf{b}} \mathbf{( \% )}$ & Flow $^{\text {Yield }}{ }^{\mathbf{a}, \mathbf{c}} \mathbf{( \% )}$ & Flow Yield $^{\text {a,d }} \mathbf{( \% )}$ \\
\hline 1 & $21-\mathrm{Cbz}$ & 75 & 76 & 71 \\
2 & 21-Boc & 75 & 64 & 72 \\
\hline
\end{tabular}

a Combined yield of both diastereomers based on the isolated amounts of products 21 . $^{\mathrm{b}}$ Batch reaction of $\mathbf{2 2}$ (0.5 mmol) using $\mathrm{PdCl}_{2} .2 \mathrm{CH}_{3} \mathrm{CN}$ ( $0.048 \mathrm{mmol}$, 0.1 equivalent), $\mathrm{CuCl}_{2}$ (1.9 mmol, 4 equivalents), $\mathrm{LiOAc}(1.9 \mathrm{mmol}$, 4 equivalents) and $\mathrm{Fe}(\mathrm{CO})_{5}(0.15 \mathrm{mmol}, 0.3$ equivalent $)$ in $1.9 \mathrm{~mL}$ of $\mathrm{AcOH}$ [68]. ${ }^{\mathrm{c}}$ Reaction was performed on $1.22 \mathrm{mmol}$ scale (substrate 22) using the conditions and flow system as described in the literature [47]. ${ }^{\mathrm{d}}$ Reaction was performed using flow system as depicted in Scheme 9.

In detail, flow transformation using new conditions as depicted in Scheme 9 provided both lactones 21 in comparable yields to reactions performed under typical conditions (Table 3, flow yield column). The new reoxidation system for $\mathrm{Pd}^{0}-\mathrm{Pd}^{\mathrm{II}}$ cycle ensures homogeneity of the reaction stream thus enabling better scaling of this flow transformation. Compared to the batch reaction (Table 3, typical conditions, batch yield column), the designed flow transformation (under new conditions) has several advantages. The batch reaction using typical conditions [47] can be undertaken only on a small scale due to the excessive pressure in the glass reaction tube. Upscaling the batch reaction $20 \mathrm{mmol}$ may cause a few problems. As $\mathrm{Fe}(\mathrm{CO})_{5}$ immediately decomposes after contact with the reaction mixture, it releases 1 equivalent of $\mathrm{CO}$ resulting in foaming and problematic stirring of heterogenous reaction mixture. Also, the pressure in a $120 \mathrm{~mL}$ reaction tube can raise up to 95 psi after few minutes.

To prove the robustness of the described flow setup, a six-hour long experiment was performed. Based on our previous experience with this type of transformation, we lowered the reaction stream concentration $(0.25 \mathrm{M}$ down to $0.125 \mathrm{M})$ to avoid the gas-liquid segment formation in the reaction coil. Continuous flow transformation of diastereomeric mixture 22-Boc ( $5.57 \mathrm{~g}$ ) using such minimally modified conditions provided the desired lactones 21-Boc in 71\% (4.5 g) combined yield (using the same flow setup as depicted in Scheme 10). However, a formation of precipitate at the exit of the reactor after cooling the reaction stream was observed. To prevent the potential clogging of the tubing, THF was employed as co-solvent in the case of a large-scale continuous reaction using 22-Cbz (Scheme 10). In this case, the prepared stock solutions of substrate $22-\mathrm{Cbz}$ and reagents were pumped directly through the HPLC pumps into the larger reactor $(47 \mathrm{~mL})$ therefore allowing us to use higher flow rates $(0.785 \mathrm{~mL} / \mathrm{min})$ and transform a larger amount of starting material 22-Cbz in shorter time. In detail, the diastereomeric mixture $\mathrm{N}-\mathrm{Cbz}$ protected aminodiols 22-Cbz (7.6 g) was easily transformed over $2.5 \mathrm{~h}$ into bicyclic lactones 21-Cbz (d.r.: 2.6:1, $6.3 \mathrm{~g}$ ) in $75 \%$ combined yield. The pure diastereomer $21-\mathrm{Cbz}$ with all syn-configuration was obtained after MPLC purification in 54\% yield (4.5 g).

In conclusion, we have designed and optimised an enhanced synthesis of the key intermediate-lactones 21-Cbz and 21-Boc utilising the stereoselective Pd-catalysed cyclocarbonylation of corresponding unsaturated aminodiols 22. The key lactones 21 were then successfully transformed into natural jaspine B 1 over a four-step sequence in batch. Also, we have demonstrated the applicability of the flow reactor in two steps preparation of $\mathrm{N}$-protected aminodiols $\mathbf{2 2}$ in comparable yields to the batch process. Importantly, new conditions for Pd-catalysed cyclocarbonylation of unsaturated polyols/aminoacohols were developed involving $p \mathrm{BQ} / \mathrm{LiCl}$ as a reoxidation system and $\mathrm{Fe}(\mathrm{CO})_{5}$ as an in situ source of stochiometric amount of carbon monoxide (only 1.5 molar equivalents). Such conditions were easily applied to continuous flow mode allowing us to prepare gram quantities of intermediates $\mathbf{2 1}$ for jaspine B $\mathbf{1}$ synthesis. This flow setup has shown several advantages compared to previous versions of the flow reaction system and the homogeneity of the reaction stream facilitated the use of a common flow system without the implementation of any other special devices. 


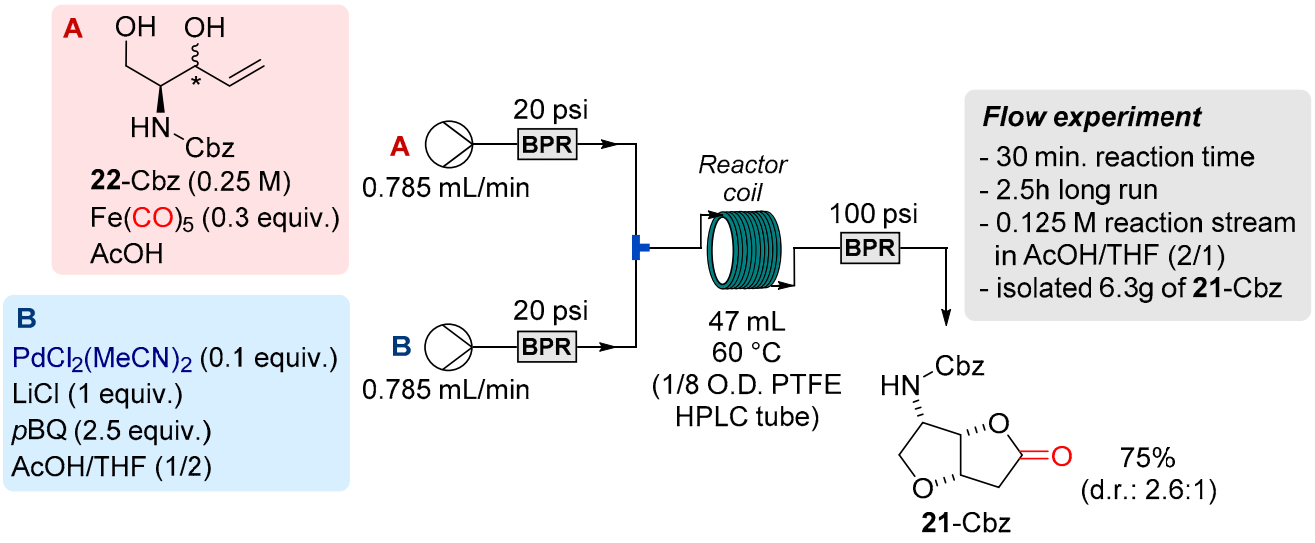

Scheme 10. Large-scale continuous synthesis of $\mathrm{N}-\mathrm{Cbz}$ protected lactone 21-Cbz.

\section{Experimental Section}

\subsection{Material and Methods}

Commercial materials which were obtained from Sigma-Aldrich, Acros Organics, Alfa Aesar or Fisher Scientific were used without further purification. Reactions were monitored using TLC on silica gel. Compound purification was undertaken by flash chromatography. All solvents were distilled before use. Hexanes refer to the fraction boiling at $60-65^{\circ} \mathrm{C}$. Flash column liquid chromatography (FLC) was performed on silica gel Kieselgel 60 (15-40 $\mu \mathrm{m}, 230-400 \mathrm{mesh}$ ) and analytical thin-layer chromatography (TLC) was performed on aluminium plates pre-coated with either $0.2 \mathrm{~mm}$ (DC-Alufolien, Merck) or $0.25 \mathrm{~mm}$ silica gel 60 F254 (ALUGRAM ${ }^{\circledR}$ SIL G/UV254, Macherey-Nagel). Analysed compounds were visualized by UV fluorescence and by dipping the plates in an aqueous $\mathrm{H}_{2} \mathrm{SO}_{4}$ solution of cerium sulphate/ammonium molybdate followed by charring with a heat gun. Melting points were obtained using a Boecius apparatus and are uncorrected. ${ }^{1} \mathrm{H}$ and ${ }^{13} \mathrm{C}$ NMR spectra were recorded on either 300 (75) MHz MercuryPlus or 600 (151) MHz Unity Inova spectrometers from Varian (Supplementary Materials). Chemical shifts $(\delta)$ are quoted in ppm and are referenced to the tetramethylsilane (TMS), $\mathrm{CDCl}_{3}$ or DMSO- $\mathrm{d}_{6}$ as internal standard. FTIR spectra were obtained on a Nicolet 5700 spectrometer (Thermo Electron) equipped with a Smart Orbit (diamond crystal ATR) accessory, using the reflectance technique (400-4000 $\mathrm{cm}^{-1}$ ). High-resolution mass spectra (HRMS) were recorded on an OrbitrapVelos mass spectrometer (Thermo Scientific, Waltham, MA, USA; Bremen, Germany) with a heated electrospray ionization (HESI) source. The mass spectrometer was operated with a full scan (50-2000 amu) in positive or negative FT mode (at a resolution of 100,000). The sample was dissolved in methanol and infused via syringe pump at a rate of $5 \mathrm{~mL} / \mathrm{min}$. The heated capillary was maintained at $275{ }^{\circ} \mathrm{C}$ with a source heater temperature of $50^{\circ} \mathrm{C}$ and the sheath, auxiliary and sweep gases were at 10,5 and 0 units, respectively. Source voltage was set to $3.5 \mathrm{kV}$.

\subsection{Representative Flow Procedures}

\subsubsection{Grignard Reaction}

The flow setup consisted of three HPLC pumps (Knauer Azura 4.1S with $10 \mathrm{~mL}$ pump head). The pumps were used to introduce a solution of substrate $26(1 \mathrm{mmol}, 0.5 \mathrm{M})$ in anhydrous THF (Feed A), a commercial solution of vinylmagnesium bromide (1.0 M in THF, Sigma-Aldrich, Feed B), and $\mathrm{MeOH}$ (Feed C). Injection loops (PTFE, $0.8 \mathrm{~mm}$ i.d., $1.6 \mathrm{~mm}$ o.d.; internal volume: $2.0 \mathrm{~mL}$, Feed A, and $2.3 \mathrm{~mL}$, Feed B) were used to deliver the two starting feeds. At start of the experiment, the whole reactor was flushed with an anhydrous THF (Feed A and Feed B) and $\mathrm{MeOH}$ (Feed C). Both solutions were loaded into their corresponding injection loops. Feed A and feed $\mathrm{B}$ were pumped from the injection loops and mixed in a T-shaped connector (PEEK) in a cooling bath $\left(0^{\circ} \mathrm{C}\right)$. The combined mixture passed through a coil reactor (PTFE, $0.8 \mathrm{~mm}$ i.d., $1.6 \mathrm{~mm}$ o.d.; internal volume: $9.0 \mathrm{~mL}$ ) at $0{ }^{\circ} \mathrm{C}$ before the mixture was combined with $\mathrm{MeOH}$ (Feed C) in a T-shaped 
connector (PEEK) at the same temperature. Final reaction mixture left the system through Upchurch BPR (15 psi). The mixture was then collected in the flask, and evaporated in vacuo. The residue was purified by MPLC (mixture of hexanes and EtOAc) providing the desired alcohols 27.

\subsubsection{Preparation of Unsaturated Aminodiols}

The flow setup consisted of three HPLC pumps (Knauer Azura 4.1S with $10 \mathrm{~mL}$ pump head). The pumps were used to introduce a solution of substrate $26(0.5 \mathrm{M})$ into anhydrous THF (Feed A), a commercial solution of vinylmagnesium bromide (1.0 $\mathrm{M}$ in THF, Sigma-Aldrich, Feed B), and quenching solvent/mixture $(\mathrm{MeOH}, \mathrm{AcOH}$, mixture $\mathrm{AcOH} / \mathrm{H}_{2} \mathrm{O}$ or $1.1 \mathrm{M}$ solution of $p$ TSA in $\mathrm{MeOH}$ ), Feed C). Injection loops (PTFE, $0.8 \mathrm{~mm}$ i.d., $1.6 \mathrm{~mm}$ o.d.; internal volume: $2.0 \mathrm{~mL}$, Feed A, and $2.3 \mathrm{~mL}$, Feed A) were used to deliver the starting two feeds. At the beginning of the experiment, the complete reactor setup was flushed with anhydrous THF (Feed A and Feed B) and corresponding solvent/mixture (according to the conditions in Table 2, Feed C). Both solutions were loaded into their corresponding injection loops. Feed A and feed B were pumped from the injection loops and mixed in a T-shaped connector (PEEK) in a cooling bath $\left(0^{\circ} \mathrm{C}\right)$. The combined mixture passed through a coil reactor (PTFE, $0.8 \mathrm{~mm}$ i.d., $1.6 \mathrm{~mm}$ o.d.; internal volume: $9.0 \mathrm{~mL}$ ) at $0{ }^{\circ} \mathrm{C}$ before the mixture was combined with Feed $\mathrm{C}$ (corresponding solvent or mixture) in a T-shaped connector (PEEK) at the same temperature. The mixture was then pumped through a second coil reactor at 50 or $70{ }^{\circ} \mathrm{C}$ (PTFE, $1.5 \mathrm{~mm}$ i.d., $3.2 \mathrm{~mm}$ o.d.; internal volume: 4.0 or $10.0 \mathrm{~mL})$ or glass Omnifit column at $40{ }^{\circ} \mathrm{C}(10 \mathrm{~mm}$ i.d. $\times 100 \mathrm{~mm}$ length $)$ filled with corresponding amount of Amberlyst 15. At the end, the reaction mixture left the system through Upchurch BPR and it was collected in the flask. The solvent from collected crude material was concentrated in vacuo (if the $p$ TSA was used, collected stream was at first quenched with saturated water solution of $\mathrm{NaHCO}_{3}$ and extracted with EtOAc). The residue was purified by MPLC (mixture of hexanes and EtOAc) providing the desired alcohol 22.

\subsubsection{Carbonylative Cyclisation Using pBQ/LiCl Reoxidation System}

The flow setup consisted of two HPLC pumps (Knauer Azura 4.1S with $10 \mathrm{~mL}$ pump head). These pumps were used to introduce a solution of substrate $22(0.25 \mathrm{M})$ and iron pentacarbonyl ( 0.3 equivalent) in glacial $\mathrm{AcOH}$ (Feed $\mathrm{A}$ ), and solution of $p \mathrm{BQ}$ (2.5 equivalents), $\mathrm{LiCl}$ (1 equivalent) and $\mathrm{PdCl}_{2}(\mathrm{MeCN})_{2}(0.1$ equivalent) in the solvent (glacial $\mathrm{AcOH}$ or $\mathrm{THF} / \mathrm{AcOH}=2: 1$, Feed B). Injection loops (PTFE, $0.8 \mathrm{~mm}$ i.d., $1.6 \mathrm{~mm}$ o.d.; internal volume: $2.0 \mathrm{~mL}$, Feed A, and $2.3 \mathrm{~mL}$, Feed B) were used to deliver the two feeds. At the beginning of the experiment, the complete reactor setup was flushed with glacial AcOH (Feed A) and corresponding solvent/mixture (Feed B). Both solutions were loaded into their corresponding injection loops. (Stock solutions were pumped directly via HPLC pumps in the case of long runs). Feed A and feed B were pumped from the injection loops and mixed in a T-shaped connector (PEEK). The combined mixture went through a reactor coil (PTFE, $0.8 \mathrm{~mm}$ i.d., $1.6 \mathrm{~mm}$ o.d.; internal volume: 17.1 or $47.1 \mathrm{~mL}$ ) at $60{ }^{\circ} \mathrm{C}$ before the flow stream left the system through Upchurch BPR (100 psi). The whole reaction stream was collected in the flask, and evaporated in vacuo. The residue was purified by MPLC (mixture of hexanes and EtOAc) providing the appropriate bicyclic lactones 21.

Supplementary Materials: The following are available online at https:/ / www.mdpi.com/article/10 $.3390 /$ catal11121513/s1. All experimental procedures for batch and flow transformations, copies of ${ }^{1} \mathrm{H}$ and ${ }^{13} \mathrm{C}$ NMR spectra for all prepared compounds are included.

Author Contributions: Experimental work, P.L., M.G. and M.M.; design of experiments M.M. and P.K.; writing—original draft preparation, writing—review and editing, P.K. and M.M.; supervision, M.M., P.K. and T.G.; project administration, P.K. and M.M.; funding acquisition, P.K. All authors have read and agreed to the published version of the manuscript. 
Funding: This research work was funded by SLOVAK GRANT AGENCIES APVV and VEGA, grant number APVV-20-0105 and VEGA No. 1/0552/18 and VEGA No. 1/0766/20.

Data Availability Statement: The datasets supporting the conclusions of this article are included within the article and Supplementary Materials.

Acknowledgments: We acknowledge the SLOVAK GRANT AGENCIES APVV, VEGA (APVV-200105 and VEGA No. 1/0552/18 and VEGA No. 1/0766/20) and Georganics Ltd. for funding.

Conflicts of Interest: The authors declare no conflict of interest.

\section{References}

1. Koruda, I.; Musman, M.; Ohtani, I.I.; Ichiba, T.; Tanaka, J.; Gravalos, D.G.; Higa, T. Pachastrissamine, a Cytotoxic Anhydrophytosphingosine from a Marine Sponge, Pachastrissa sp. J. Nat. Prod. 2002, 65, 1505-1506. [CrossRef]

2. Ledroit, V.; Debitus, C.; Lavaud, C.; Massiot, G. Jaspines A and B: Two new cytotoxic sphingosine derivatives from the marine sponge Jaspis sp. Tetrahedron Lett. 2003, 44, 225-228. [CrossRef]

3. Canals, D.; Moemenoe, D.; Farias, G.; Llebaria, A.; Casa, J.; Delgado, A. Synthesis and biological properties of Pachastrissamine (jaspine B) and diastereoisomeric jaspines. Bioorg. Med. Chem. 2009, 17, 235-241. [CrossRef] [PubMed]

4. Ghosal, P.; Ajay, S.; Meena, S.; Sinha, S.; Shaw, A.K. Stereoselective total synthesis of jaspine B (pachastrissamine) utilizing iodocyclization and an investigation of its cytotoxic activity. Tetrahedron Asymmetry 2013, 24, 903-908. [CrossRef]

5. Salma, Y.; Lafont, E.; Therville, N.; Carpentier, S.; Bonnafé, M.-J.; Levade, T.; Génisson, Y.; Andrieu-Abadie, N. The natural marine anhydrophytosphingosine, Jaspine B, induces apoptosis in melanoma cells by interfering with ceramide metabolism. Biochem. Pharmacol. 2009, 78, 477-485. [CrossRef]

6. Jayachitra, G.; Sudhakar, N.; Anchoori, R.K.; Rao, B.V.; Roy, S.; Banerjee, R. Stereoselective synthesis and biological studies of the C2 and C3 epimer and the enantiomer of Pachastrissamine (Jaspine B). Synthesis 2010, 1, 115-119.

7. Xu, J.-M.; Zhang, E.; Shi, X.-J.; Wang, Y.-C.; Yu, B.; Jiao, W.-W.; Guo, Y.-Z.; Liu, H.-M. Synthesis and preliminary biological evaluation of 1,2,3-triazole-Jaspine B hybrids as potential cytotoxic agents. Eur. J. Med. Chem. 2014, 80, 593-604. [CrossRef]

8. Martinková, M.; Mezeiová, E.; Fabišíková, M.; Gonda, J.; Pilátová, M.; Mojžiš, J. Total synthesis of pachastrissamine together with its 4-epi-congener via [3,3]-sigmatropic rearrangements and antiproliferative/cytotoxic evaluation. Carbohyde. Res. 2015, 402, 6-24. [CrossRef]

9. Santos, C.; Fabing, I.; Saffon, N.; Ballereau, S.; Génisson, Y. Rapid access to jaspine B and its enantiomer. Tetrahedron 2013, 69, 7227-7233. [CrossRef]

10. Jeon, H.; Bae, H.; Baek, D.; Kwak, Y.-S.; Kim, D.; Kim, S. Syntheses of sulfur and selenium analogues of pachastrissamine via double displacements of cyclic sulfate. Org. Biomol. Chem. 2011, 9, 7237-7242. [CrossRef]

11. Rives, A.; Ladeira, S.; Levade, T.; Andrieu-Abadie, N.; Génisson, Y. Synthesis of Cytotoxic Aza Analogues of Jaspine B. J. Org. Chem. 2010, 75, 7920-7923. [CrossRef]

12. Salma, Y.; Ballereau, S.; Maaliki, C.; Ladeira, S.; Andrieu-Abadie, N.; Génisson, Y. Flexible and enantioselective access to jaspine B and biologically active chain-modified analogues thereof. Org. Biomol. Chem. 2010, 8, 3227-3243. [CrossRef]

13. Salma, Y.; Ballereau, S.; Ladeira, S.; Lepetit, C.; Chauvin, R.; Andrieu-Abadie, N. Single- and double-chained truncated jaspine B analogues: Asymmetric synthesis, biological evaluation and theoretical study of an unexpected 5-endo-dig process. Tetrahedron 2011, 67, 4253-4262. [CrossRef]

14. Ballereau, S.; Andrieu-Abadie, N.; Saffon, N.; Génisson, Z. Synthesis and biological evaluation of aziridine-containing analogs of phytosphingosine. Tetrahedron 2011, 67, 2570-2578. [CrossRef]

15. Pashikanti, A.; Ukani, R.; David, S.A.; Datta, A. Total Synthesis and Structure-Activity Relationship Studies of the Cytotoxic Anhydrophytosphingosine Jaspine B (Pachastrissamine). Synthesis 2017, 49, 2088-2100.

16. Schmiedel, V.M.; Stefani, S.; Reissig, H.-U. Stereodivergent synthesis of jaspine B and its isomers using a carbohydrate-derived alkoxyallene as C3-building block. Beilstein. J. Org. Chem. 2013, 9, 2564-2569.

17. Dhand, V.; Chang, S.; Britton, R. Total Synthesis of the Cytotoxic Anhydrophytosphingosine Pachastrissamine (Jaspine B). J. Org. Chem. 2013, 78, 8208-8213. [CrossRef]

18. Enders, D.; Terteryan, V.; Paleček, J. Asymmetric Synthesis of Jaspine B (Pachastrissamine) via an Organocatalytic Aldol Reaction as Key Step. Synthesis 2008, 14, 2278-2282. [CrossRef]

19. Urano, H.; Enomoto, M.; Kuwahara, S. Enantioselective Syntheses of Pachastrissamine and Jaspine A via hydroxylactonization of a Chiral Epoxy Ester. Biosci. 2010, 74, 152-157.

20. Llaveria, J.; Díaz, Y.; Matheu, M.I.; Castillón, S. Eur. Enantioselective Synthesis of Jaspine B (Pachastrissamine) and Its C-2 and/or C-3 Epimers. J. Org. Chem. 2011, 1514-1519.

21. Alnazer, H.; Castellan, T.; Salma, Y.; Génissom, Y.; Ballereau, S. Enantioselective Stereodivergent Synthesis of Jaspine B and 4-epi-Jaspine B from Axially Chiral Allenols. Synlett 2019, 30, 185-188.

22. Yakura, T.; Sato, S.; Yoshimoto, Y. Enantioselective Synthesis of Pachastrissamine (Jaspin B) Using Dirhodium(II)-Catalyzed C-H Amination and Asymmetric Dihydroxylation as Key Steps. Chem. Pharm. Bull. 2007, 55, 1284-1286. [CrossRef] [PubMed] 
23. Abraham, E.; Candela-Lena, J.; Davies, S.G.; Georgiou, M.; Nicholson, R.L.; Roberts, P.M.; Russell, A.J.; Sánchez-Fernández, E.M.; Smith, A.D.; Thomson, J.E. Asymmetric synthesis of $\mathrm{N}, \mathrm{O}, \mathrm{O}, \mathrm{O}$-tetra-acetyl D-lyxo-phytosphingosine, jaspine B (pachastrissamine) and its C(2)-epimer. Tetrahedron Asymmetry 2007, 18, 2510-2513. [CrossRef]

24. Abraham, E.; Brock, E.A.; Candela-Lena, J.; Davies, S.G.; Georgiou, M.; Nicholson, R.L.; Perkins, J.H.; Roberts, P.M.; Russell, A.J.; Sánchez-Fernández, E.M.; et al. Asymmetric synthesis of $\mathrm{N}, \mathrm{O}, \mathrm{O}, \mathrm{O}$-tetra-acetyl D-lyxo-phytosphingosine, jaspine B (pachastrissamine), 2-epi-jaspine B, and deoxoprosophyllinevialithium amide conjugate addition. Org. Biomol. Chem. 2008, 6 , 1665-1673.

25. Inuki, S.; Yoshimitsu, Y.; Oishi, S.; Fujii, N.; Ohno, H. Ring-Construction/Stereoselective Functionalization Cascade: Total Synthesis of Pachastrissamine (Jaspine B) through Palladium-Catalyzed Bis-cyclization of Bromoallenes. Org. Lett. 2009, 11, 4478-4481. [CrossRef] [PubMed]

26. Inuki, S.; Yoshimitsu, Y.; Oishi, S.; Fujii, N.; Ohno, H. Ring-Construction/Stereoselective Functionalization Cascade: Total Synthesis of Pachastrissamine (Jaspine B) through Palladium-Catalyzed Bis-cyclization of Propargyl Chlorides and Carbonates. J. Org. Chem. 2010, 75, 3831-3842. [CrossRef]

27. Yoshimitsu, Y.; Inuki, S.; Oishi, S.; Fujii, N.; Ohno, H. Stereoselective Divergent Synthesis of Four Diastereomers of Pachastrissamine(Jaspine B). J. Org. Chem. 2010, 75, 3843-3846. [CrossRef]

28. Passiniemi, M.; Koskinen, A.M.P. Asymmetric synthesis of Pachastrissamine (Jaspine B) and its diastereomers via $\eta 3$ allylpalladium intermediates. Org. Biomol. Chem. 2011, 9, 1774-1783. [CrossRef] [PubMed]

29. Yoshimitsu, Y.; Miyagaki, J.; Oishi, S.; Fujii, N.; Ohno, H. Synthesis of pachastrissamine (jaspine B) and its derivatives by the late-stage introduction of the C-2 alkyl side-chains using olefin crossmetathesis. Tetrahedron 2013, 69, 4211-4220. [CrossRef]

30. Jana, A.K.; Panda, G. Stereoselective synthesis of Jaspine B and its C2 epimer from Garner aldehyde. RSC Adv. 2013, 3, 16795-16801. [CrossRef]

31. Yoshimitsu, Y.; Oishi, S.; Miyagaki, J.; Inuki, S.; Ohno, H.; Fujii, N. Pachastrissamine (jaspine B) and its stereoisomers inhibit sphingosine kinases and atypical protein kinase C. Bioorg. Med. Chem. 2011, 19, 5402-5408. [CrossRef] [PubMed]

32. Bae, H.; Jeon, H.; Baek, D.J.; Lee, D.; Kim, S. Stereochemically Reliable Syntheses of Pachastrissamine and Its 2-epi-Congener via Oxazolidinone Precursors from an Established Starting Material N-tert-Butoxycarbonyl-Protected Phytosphingosine. Synthesis 2012, 44, 3609-3612.

33. Vichare, P.; Chattopadhyay, A. Nitrolaldol reaction of (R)-2,3-cyclohexylideneglyceraldehyde: A simple and stereoselective synthesis of the cytotoxic Pachastrissamine (Jaspine B). Tetrahedron Asymmetry 2010, 21, 1983-1987. [CrossRef]

34. Ichikawa, Y.; Matsunaga, K.; Masuda, T.; Kotsuki, H.; Nakano, K. Stereocontrolled synthesis of cytotoxic anhydrosphingosine pachastrissamine by using [3.3] sigmatropic rearrangement of allyl cyanate. Tetrahedron 2008, 64, 11313-11318. [CrossRef]

35. Bhaket, P.; Morris, K.; Stauffer, C.S.; Datta, A. Total Synthesis of Cytotoxic Anhydrophytosphingosine Pachastrissamine (Jaspine B). Org. Lett. 2005, 7, 875-876. [CrossRef]

36. Lee, H.-J.; Lim, C.; Hwang, S.; Jeong, B.-S.; Kim, S. Silver-Mediated exo-Selective Tandem Desilylative Bromination/Oxycyclization of Silyl-Protected Alkynes: Synthesis of 2-Bromomethylene-Tetrahydrofuran. Chem. Asian J. 2011, 6, 1943-1947. [CrossRef]

37. Prasad, K.R.; Chandrakumar, A. Stereoselective Synthesis of Cytotoxic Anhydrophytosphingosine Pachastrissamine [Jaspine B]. J. Org. Chem. 2007, 72, 6312-6315. [CrossRef]

38. Lee, T.; Lee, S.; Kwak, Y.S.; Kim, D.; Kim, S. Synthesis of Pachastrissamine from Phytosphingosine: A Comparison of Cyclic Sulfate vs an Epoxide Intermediate in Cyclization. Org. Lett. 2007, 9, 429-432. [CrossRef] [PubMed]

39. Van der Berg, R.J.B.H.N.; Boltje, T.J.; Verhagen, C.P.; Litjens, E.J.N.; Van der Marel, G.A.; Overkleeft, H.S. An Efficient Synthesis of the Natural Tetrahydrofuran Pachastrissamine Starting from D-ribo-Phytosphingosine. J. Org. Chem. 2006, 71, 836-839. [CrossRef]

40. Fujiwara, T.; Liu, B.; Niu, W.; Hashimoto, K.; Nambu, H.; Yakura, T. Practical Synthesis of Pachastrissamine (Jaspine B), 2-epi-Pachastrissamine, and the 2-epi-Pyrrolidine Analogue. Chem. Pharm. Bull. 2016, 64, 179-188. [CrossRef]

41. Du, Y.; Liu, J.; Linhardt, R.J. Stereoselective Synthesis of Cytotoxic Anhydrophytosphingosine Pachastrissamine (Jaspine B) from D-Xylose. J. Org. Chem. 2006, 71, 1251-1253. [CrossRef] [PubMed]

42. Reddy, L.V.R.; Reddy, P.V.; Shaw, A.K. An expedient route for the practical synthesis of pachastrissamine (jaspine B) starting from 3,4,6-tri-O-benzyl-D-galactal. Tetrahedron Asymmetry 2007, 18, 542-546. [CrossRef]

43. Ribes, C.; Falomir, E.; Carda, M.; Marco, J.A. Stereoselective synthesis of pachastrissamine (jaspine B). Tetrahedron 2006, 62, 5421-5425. [CrossRef]

44. Ramana, C.V.; Giri, A.G.; Suryawanshi, S.B.; Gonnade, R.G. Total synthesis of pachastrissamine (jaspine B) enantiomers from d-glucose. Tetrahedron Lett. 2007, 48, 265-268. [CrossRef]

45. Rao, G.S.; Rao, B.V. A common strategy for the stereoselective synthesis of anhydrophytosphingosine pachastrissamine (jaspine B) and $\mathrm{N}, \mathrm{O}, \mathrm{O}, \mathrm{O}$-tetra-acetyl D-lyxo-phytosphingosine. Tetrahedron Lett. 2011, 52, 6076-6079.

46. Kwon, Y.; Song, J.; Bae, H.; Kim, W.J.; Lee, J.Y.; Han, G.H.; Lee, S.K.; Kim, S. Synthesis and Biological Evaluation of Carbocyclic Analogues of Pachastrissamine. Mar. Drugs 2015, 13, 824-837. [CrossRef] [PubMed]

47. Lopatka, P.; Markovič, M.; Koóš, P.; Ley, S.L.; Gracza, T. Continuous Pd-Catalyzed Carbonylative Cyclization Using Iron Pentacarbonyl as a CO Source. J. Org. Chem. 2019, 84, 14394-14406. [CrossRef] [PubMed]

48. Markovič, M.; Koóš, P.; Gracza, T. A Short Asymmetric Synthesis of Sauropunols A-D. Synthesis 2017, 49, $2939-2942$.

49. Markoviš, M.; Koóš, P.; Čarný, T.; Sokoliová, S.; Boháčiková, N.; Moncol', J.; Gracza, T. Total Synthesis, Configuration Assignment, and Cytotoxic Activity Evaluation of Protulactone A. J. Nat. Prod. 2017, 80, 1631-1638. [CrossRef] 
50. Lopatka, P.; Koóš, P.; Markovič, M.; Gracza, T. Asymmetric Formal Synthesis of (+)-Pyrenolide D. Synthesis 2014, 46, 817-821.

51. Koóš, P.; Špánik, I.; Gracza, T. Asymmetric intramolecular Pd (II)-catalysed amidocarbonylation of unsaturated amino alcohols. Tetrahedron Asymmetry 2009, 20, 2720-2723. [CrossRef]

52. Kapitán, P.; Gracza, T. Stereocontrolled oxycarbonylation of 4-benzyloxyhepta-1,6-diene-3,5-diols promoted by chiral palladium (II) complexes. Tetrahedron Asymmetry 2008, 19, 38-44. [CrossRef]

53. McKillop, A.; Taylor, R.; Watson, R.; Lewis, N. An Improved Procedure for the Preparation of the Garner Aldehyde and Its Use for the Synthesis of N-Protected 1-Halo-2(R)-amino-3-butanes. Synthesis 1994, 1, 31-33. [CrossRef]

54. Ojima, I.; Vidal, S.E. Rhodium-Catalyzed Cyclohydrocarbonylation: Application to the Synthesis of (+)-Prosopinine and (-)Deoxoprosophylline. J. Org. Chem. 1998, 63, 7999-8003. [CrossRef]

55. Ghosh, A.; Chattopadhyay, S.K. A diversity oriented synthesis of D-erythro-sphingosine and siblings. Tetrahedron Asymmetry 2017, 28, 1139-1143. [CrossRef]

56. Ghosal, P.; Shaw, A.K. An efficient total synthesis of the anticancer agent (+)-spisulosine (ES-285) from Garner's aldehyde. Tetrahedron Lett. 2010, 51, 4140-4142. [CrossRef]

57. Singh, P.; Panda, G. Intramolecular 5-endo-trig aminopalladation of $\beta$-hydroxy- $\gamma$-alkenylamine: Efficient route to apyrrolidine ring and its application for the synthesis of (-)-8,8a-di-epi-swainsonine. RSC Adv. 2014, 4, 2161-2166. [CrossRef]

58. Abraham, E.; Davies, S.G.; Roberts, P.M.; Russell, A.J.; Thomson, J.E. Jaspine B (pachastrissamine) and 2-epi-jaspine B:synthesis and structural assignment. Tetrahedron Asymmetry 2008, 19, 1027. [CrossRef]

59. Porta, R.; Benaglia, M.; Puglisi, A. Flow Chemistry: Recent Developments in the Synthesis of Pharmaceutical Products. Org. Preocess Res. Dev. 2016, 1, 2-25. [CrossRef]

60. Brandão, P.; Pineiro, M.; Pinho e Melo, T.M. Flow Chemistry: Towards A More Sustainable Heterocyclic Synthesis. Eur. J. Org. Chem. 2019, 43, 7188-7217. [CrossRef]

61. Levesque, F.; Seeberger, F.H. Continuous-Flow Synthesis of the Anti-Malaria Drug Artemisinin. Angew. Chem. Int. Ed. 2012, 51, 1706-1709. [CrossRef]

62. Lau, S.-H.; Galván, A.; Merchant, R.R.; Battilocchio, C.; Souto, J.A.; Berry, M.B.; Ley, S.V. Machines vs Malaria: A Flow-Based Preparation of the Drug Candidate OZ439. Org. Lett. 2015, 17, 3218-3221. [CrossRef] [PubMed]

63. LaPorte, T.L.; Spangler, L.; Hamedi, M.; Lobben, P.; Chan, S.H.; Mushlehiddinoglu, J.; Wang, S.S.Y. Development of a Continuous Plug Flow Process for Preparation of a Key Intermediate for Brivanib Alaninate. Org. Process Res. Dev. 2014, 18, 1492-1502. [CrossRef]

64. Baxendale, I.R.; Griffiths-Jones, C.M.; Ley, S.V.; Tranmer, G.K. Preparation of the Neolignan Natural Product Grossamide by a Continuous-Flow Process. Synlett 2006, 3, 427-430. [CrossRef]

65. Correia, C.A.; Gilmore, K.; McQuade, D.T.; Seeberger, P.H. A Cocise Flow Synthesis of Efavirenz. Angew. Chem. Int. Ed. 2015, 54, 4945-4948. [CrossRef] [PubMed]

66. Tsubogo, T.; Oyamada, H.; Kobayashi, S. Multistep continuous-flow synthesis of (R)- and (S)-rolipram using heterogeneous catalysts. Nature 2015, 520, 329-332. [CrossRef]

67. Hartwig, J.; Ceylan, S.; Kupracz, L.; Coutable, L.; Kirschning, A. Heating under High-Frequency Inductive Conditions: Application to the Continuous Synthesis of the Neurolepticum Olanzapine (Zyprexa). Angew. Chem. Int. Ed. 2013, 52, 9813-9817. [CrossRef] [PubMed]

68. Babjak, M.; Markovič, M.; Kandríková, B.; Gracza, T. Homogeneous Cyclocarbonylation of Alkenols with Iron Pentacarbonyl. Synthesis 2014, 46, 809-816. [CrossRef] 